\title{
Screening of Different Rice Germplasm against Multiple Disease under Submergence Condition in Middle Indo Gangetic Plain
}

\author{
Santosh Kumar, S.K. Dwivedi, Rahul Kumar*, N. Bhakta, Ved Prakash, K.K. Rao, Rakesh \\ Kumar, Shikha Yadav, Anup Kumar Choubey and J.S. Mishra
}

\author{
ICAR-Research Complex for Eastern Region Patna-800014 (Bihar), India \\ *Corresponding author
}

\begin{tabular}{|c|c|}
\hline & A B S T R A C T \\
\hline Keywords & \multirow{4}{*}{$\begin{array}{l}\text { The present study was conducted at the experimental farm of ICAR Research } \\
\text { Complex for Eastern Region, Patna, India in Kharif season } 2016 \text { with an objective } \\
\text { to identify sheath blight and bacterial leaf blight disease resistance rice genotypes } \\
\text { under submergence condition in middle Indo Gangetic Plain. The disease } \\
\text { incidence was observed at maturity stages during Kharif season 2016. The } \\
\text { incidence of sheath blight and bacterial leaf blight of paddy ranged from } 18.6 \text { to } \\
39.0 \% \text { and } 15.3 \text { to } 34.0 \% \text {, respectively. Among the rice genotypes, the minimum } \\
\text { disease incidence of sheath blight was recorded in IR 96321-1447-521-B-2-1-2; } \\
\text { minimum bacterial leaf blight disease incidence was recorded in IR96321-1099- } \\
227-B-3-1-3 \text {. The resistance genotypes may be further utilized as the genetic } \\
\text { sources in disease resistance rice breeding programme. }\end{array}$} \\
\hline $\begin{array}{l}\text { Rice, Genotypes, } \\
\text { Disease, } \\
\text { Submergence, } \\
\text { Sheath blight and } \\
\text { bacterial leaf blight. }\end{array}$ & \\
\hline Article Info & \\
\hline $\begin{array}{l}\text { Accepted: } \\
\text { 04 April } 2017\end{array}$ & \\
\hline
\end{tabular}

\section{Introduction}

Rice (Oryza sativa L.) is the staple food of more than three billion people in the world; most of them live in Asia (IRRI, 2009). Rice is cultivated under diverse ecologies, ranging from irrigated to rain-fed and upland to lowland and deep water system (Kumar et al., 2014). Rainfed lowlands constitute highly fragile ecosystems, prone to flash-flood with an average productivity of only $1.2 \mathrm{t} \mathrm{ha}^{-1}$ in normal years and hardly $0.5 \mathrm{t} / \mathrm{ha}$ in case of submergence (Sarker et al., 2006). Plants require water for growth and development, but excessive water negatively affects their productivity and viability. Flash floods occasionally result in complete submergence of plants in agricultural and natural ecosystems. When immersed in water, plants encounter multiple stresses including low oxygen, low light, nutrient deficiency, and high risk of infection. Eastern India alone has approximately $10 \mathrm{~m}$ ha of rice lands affected by flash floods and completes submergence (Ram et al., 2002). Rice is very sensitive to water stress, and any attempt to reduce water input may tax true yield potential (Fukai and Cooper, 1995). Generally rice crop is affected by more than 17 diseases and certain diseases are more common on rice varieties than on conventional varieties. Among the different diseases brown spot, sheath blight, blast, stem rot and bacterial leaf blight are considered important in various parts of rice growing 
areas of the world. Sheath blight is an important soil borne disease caused by Rhizoctonia solani that can cause up to $25 \%$ yield loss (Kumar et al., 2009). Bacterial leaf blight is caused by Xanthomonas oryzae occurs mostly during the wet season and in some areas of Asia, which can reduce crop yield by up to $50 \%$ (Latif et al., 2011). Keeping this in view, the present study was undertaken to evaluate of 12 rice genotypes for resistance and susceptibility against sheath blight and bacterial leaf blight disease.

\section{Materials and Methods}

A field experiment was conducted during Kharif seasons of 2016 at ICAR Research Complex for Eastern Region, Patna (Latitude: $25^{0} 30^{`} \mathrm{~N}$, Longitude: $85^{\circ} 15^{`} \mathrm{E}$, Elevation: 52 $\mathrm{m}$ above mean sea level), Bihar, India under rainfed lowland submergence-prone ecosystem. The old alluvial soils of the experimental site are located in the Middle Indo-Gangetic Plains having subtropical humid climate and grouped under the soil sub order of Ustepts in the order Inceptisols. The soil of the experiments was loam in texture, low in organic carbon and available nitrogen, high in available phosphorus and medium in available potassium with slightly alkaline in reaction during wet season 2016. Nursery was raised using pre-germinated seeds@ @ 40g m ${ }^{-2}$, and N: P: K @ 75-21.8 -41.7 kg ha ${ }^{-1}$ was applied. Half $\mathrm{N}$, full $\mathrm{P}$ and $\mathrm{K}$ in the form of prilled urea, single super phosphate and muriate of potash, respectively were applied as basal and remaining $1 / 2 \mathrm{~N}$ was applied at $15^{\text {th }}$ day after seeding. For submergenceprone environment, thirty days old seedlings were transplanted at $20 \times 15 \mathrm{~cm}$ spacing with one seedling per hill in the main field and 80$17.5-05 \mathrm{~kg} \mathrm{ha}^{-1}$ nitrogen, phosphorus and zinc were applied as per area specific recommended rates. The experiment was conducted in RBD with 3 replications. Plants were subjected to three times complete submergence [first time for a period of 18 days (after 10 days of transplanting) second times for 10 days (10 days after first recovery) and third times for five days (20 days after second recovery)]. A desired water depth $(1.25 \mathrm{~m})$ was maintained by adding additional water regularly in the ponds.

\section{Assessment of the disease incidence}

Each plot was visited on regular basis for recording observations. The disease incidence was recorded at three different growth stages of the plant viz., flowering, milk and maturity stage. Data were recorded visually by observing the symptoms. Sixteen plants were randomly selected from each unit plot and the following parameters were considered for data collection.

Number of tillers / plants

Number diseased tillers / plants

Percent leaf area diseased (LAD)

Disease incidence was calculated by the following formula (Rajput and Bartaria, 1995):

Disease incidence $=$ Number of diseased tillers/

Total number of inspected tillers x 100

Isolation and identification of causal organism

The leaves from the diseased plants were collected from the field and cut into small pieces along with healthy portion. Cut pieces were sterilized by the surface disinfectants e.g. $0.1 \%$ mercuric chloride for 30 seconds. After sterilization the cut pieces were washed three times with sterile water. The cut pieces were then placed on sterile blotter paper to remove excess water. The cut pieces were then placed on the Potato Dextrose Agar plate. The plate were labelled and placed in the incubation chamber for 7 days at $25+$ 
$2^{\circ} \mathrm{C}$. After 7 days of incubation, the fungi grown on culture media. A portion of culture was taken on slide and observed under microscope and identified the pathogenic fungi i.e. Rhizoctonia solani, with the help of relevant literature (Mew and Gonzales, 2002; Barnet and Hunter, 1972). In bacterial leaf blight causal organism Xanthomonas oryzae isolated on nutrient Agar media. A portion of culture was taken by inoculating needle on another Potato Dextrose Agar and nutrient Agar media plates. A small portion from the subculture was inoculated to another Potato Dextrose Agar and nutrient Agar plate for pure culture. The pathogen, thus purified, was kept in refrigerator for future use. All these operations were done aseptically in the laminar air flow chamber.

\section{Analysis of data}

The data on different characters were subjected to estimates of ANOVA (analysis of variance) by using statistical software OPSTAT.

\section{Results and Discussion}

Evaluation of rice varieties against disease incidence

The results of evaluation of twelve rice genotypes against sheath blight and bacterial leaf blight diseases revealed that minimum disease incidence was observed in IR 963211447-521-B-2-1-2(18.6\%) followed by IR 96321-1099-227-B-3-1-3 (19.0\%) (Table 1). Significant differences were observed among rice genotypes for resistance to Sheath blight disease. The disease scoring against sheath blight was varied from 18.6 to $39.07 \%$. Maximum disease incidence was observed in IR 96321-558-563-B-2-1-1 (39.0\%) followed by IR 96321-1447-651-B-1-1-2 (38.6\%) (Fig. 1). The similar result was also reported by Alam (2007), who observed the maximum infection index at soft dough stage and minimum infection index at maximum tillering stage. Mosaddeque et al., (2008) also found highest disease severity (5.18) of sheath blight on BR-111 and lowest severity (0.50) on resistant line (Accession No. 08R).

Table.1 Screening of different rice germplasm against sheath blight of rice

\begin{tabular}{|r|l|c|}
\hline \multicolumn{1}{|c|}{ S1. No. } & \multicolumn{1}{|c|}{ Name of genotypes } & Disease Incidence (\%) \\
\hline 1 & R 96321-558-257-B-4-1-2 & 37.67 \\
\hline 2 & IR 96322-34-127-B-2-1-3 & 26.33 \\
\hline 3 & IR 96321-1447-521-B-2-1-2 & 18.67 \\
\hline 4 & IR 96321-1447-651-B-1-1-2 & 38.67 \\
\hline 5 & IR 96321-558-209-B-6-1-1 & 33.33 \\
\hline 6 & IR 96321-315-323-B-3-1-1 & 28.33 \\
\hline 7 & IR 96321-315-323-B-3-1-3 & 21.33 \\
\hline 8 & IR 96321-558-563-B-2-1-1 & 39.00 \\
\hline 9 & IR 96321-558-563-B-2-1-3 & 30.33 \\
\hline 10 & IR 96321-1099-227-B-3-1-3 & 19.00 \\
\hline 11 & Swarna sub 1 & 36.33 \\
\hline 12 & Swarna & 32.33 \\
\hline & $\boldsymbol{S E}(\boldsymbol{m})$ & $\mathbf{1 . 8 2}$ \\
\hline & $\boldsymbol{L S D}(\boldsymbol{0 . 0 5})$ & $\mathbf{5 . 3 7}$ \\
\hline
\end{tabular}


Table.2 Screening of different rice germplasm against bacterial leaf blight of rice

\begin{tabular}{|r|l|c|}
\hline \multicolumn{1}{|c|}{ S1. No. } & \multicolumn{1}{|c|}{ Name of genotypes } & Disease Incidence (\%) \\
\hline 1 & IR 96321-558-257-B-4-1-2 & 21.67 \\
\hline 2 & IR 96322-34-127-B-2-1-3 & 17.33 \\
\hline 3 & IR 96321-1447-521-B-2-1-2 & 25.67 \\
\hline 4 & IR 96321-1447-651-B-1-1-2 & 34.00 \\
\hline 5 & IR 96321-558-209-B-6-1-1 & 22.33 \\
\hline 6 & IR 96321-315-323-B-3-1-1 & 23.00 \\
\hline 7 & IR 96321-315-323-B-3-1-3 & 22.00 \\
\hline 8 & IR 96321-558-563-B-2-1-1 & 29.33 \\
\hline 9 & IR 96321-558-563-B-2-1-3 & 21.67 \\
\hline 10 & IR 96321-1099-227-B-3-1-3 & 15.33 \\
\hline 11 & Swarna sub 1 & 16.67 \\
\hline 12 & Swarna & 16.33 \\
\hline & SE (m) & $\mathbf{1 . 7 5}$ \\
\hline & LSD $(0.05)$ & $\mathbf{5 . 1 5}$ \\
\hline
\end{tabular}

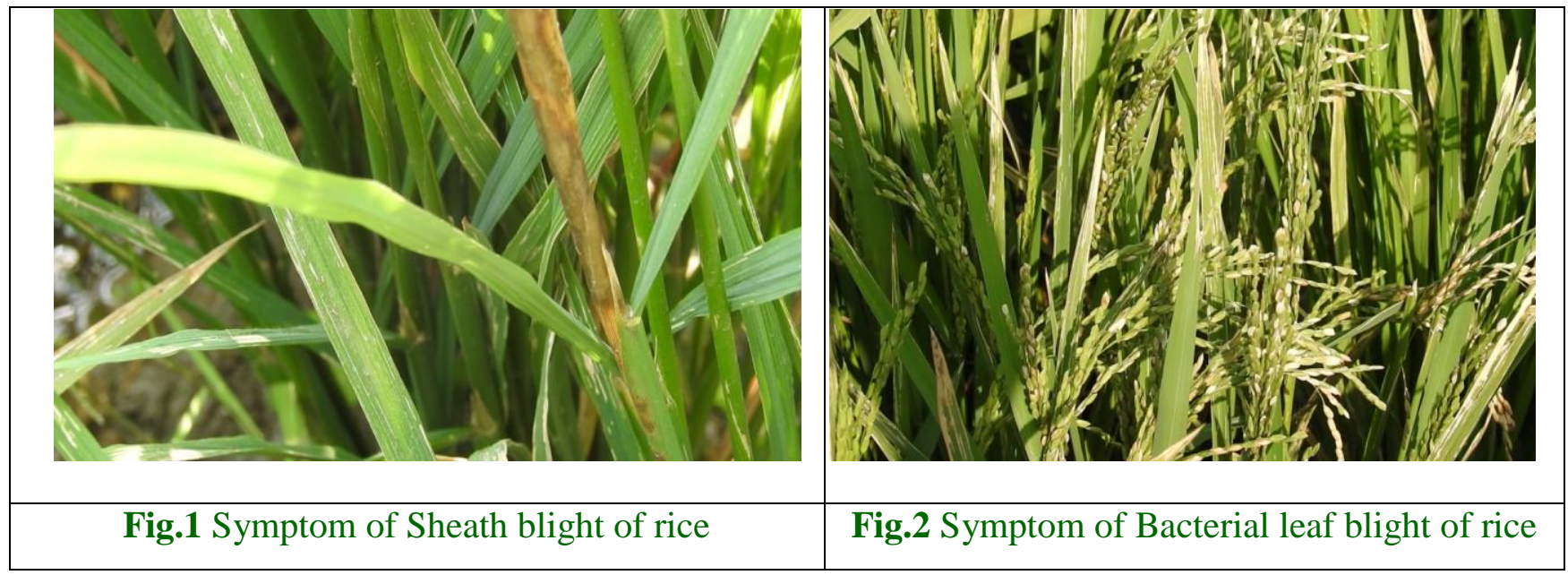

The incidence of bacterial leaf blight ranged from 15.3 to $34.0 \%$ at maturity stages (Table $2)$. The highest incidence of bacterial leaf blight was observed in 'IR 96321-1447-651B-1-1-2' (34.0\%) followed by 'IR 96321-558257-B-4-1-2' (31.77\%) whereas the lowest incidence of bacterial leaf blight was recorded on 'IR 96321-1099-227-B-3-1-3' followed by Swarna (Fig. 2). These finding were supported by Akhtar et al., (2003) who found that BLB disease of rice prompted by Xanthomonas oryzae pv. oryzae has created a serious situation in all provinces of Pakistan viz., Punjab, Khyber Pakhtukhwa, Sindh,
Baluchistan including Pakistan occupied Kashmir.

Based on above findings it is concluded that among all rice genotypes, the minimum disease incidence of sheath blight was recorded in IR 96321-1447-521-B-2-1-2; minimum bacterial leaf blight disease incidence was recorded in IR96321-1099227-B-3-1- 3. Maximum disease incidence were observed in genotype IR 96321-558563-B-2-1-1 and IR 96321-1447-651-B-1-1-2 respectively sheath blight and bacterial leaf blight. In the present study, the promising 
resistance genotypes may be further utilized as the genetic sources in disease resistance rice breeding programme.

\section{Acknowledgements}

The authors are grateful to the International Rice Research Institute (IRRI) for providing experimental materials for this study.

\section{References}

Akhtar, M.A., Zakria, M., Abbasi, F.M. and Masood, M.A. 2003. Incidence of bacterial blight of rice in Pakistan during 2002. Pak. J. Bot., 35: 993-997.

Alam, M.M. 2007. An investigation into disease incidence, grains yield and quality of BRRI dhan29 at BAU farm. MS thesis, Department of Plant Pathology, Bangladesh, Agri. Uni., Mymensingh, pp: 29.

Fukai, S., Cooper, M. 1995. Development of drought-resistant cultivars using physiomorphological traits in rice. Field crop Res., 40: 67-86.

IRRI. 2009. Rough rice production by country and geographical region-USDA. Trend in the rice economy. In: world rice statistics. www.irri.org/science/ricestat

Kumar, K.V.K., M.S. Reddy, J.W. Kloepper, K.S. Lawrence, D.E. Groth and M.E. Miller. 2009. Sheath blight disease of rice (Oryza sativa L.): An overview. Biosci. Biotechnol. Res. Asia, 6: 465-480.

Kumar, S., Dwivedi, S. K., Singh, S.S., Elanchezhian, R., Mehta, P., Singh, B.P., Singh, O.N., and Bhatt, B.P. 2014. Morpho-physiological traits associated with reproductive stage drought tolerance of rice (Oryza sativa L.) genotypes under rain-fed condition of eastern IndoGangetic plain. Indian J. Plant Physiol., 19(2):87-93.

Latif, M.A., M.A. Badsha, M.I. Tajul, M.S. Kabir, M.Y. Rafii and M.A.T. Mia. 2011 Identification of genotypes resistant to blast, bacterial leaf blight, sheath blight and tungro and efficacy of seed treating fungicides against blast disease of rice. Sci. Res. Essays, 6: 2804-2811.

Mew, T.W., Gonazales, P. 2002. A handbook of rice seed bore fungi, International Rice Research Institute, Los Banos, Philippines; pp: 20.

Mosaddeque, H.Q.M., M.I. Talukder, M.M. Islam, A.K.M. Khusrul and M.A. Alam. 2008. Screening of some restorer and maintainer hybrid rice lines against sheath blight (Rhizoctonia solani). J. Soil Nat., 2: 23-29.

Rajput, R.L. and A.M. Bartaria. 1995. Reaction of rice cultivars to brown spot. Agric. Sci. Dig. J., 15: 205-206.

Ram, P.C., Singh, B.B., Singh, A.K., Ram, P., Singh, P.N., Singh, H.P., Boamfa, E.I., Hareen, F.J.M., Santosa, E. and Jackson, M.B. 2002. Physiological basis of submergence tolerance in rainfed lowland rice: prospects of germplasm improvement through marker aided breeding. Field Crops Res., 76: 131-152.

Sarkar, R.K., Reddy, J.N., Sharma, S.G., Ismail, A.M. 2006. Physiological basis of submergence tolerance in rice and implications for crop improvement. Curr. Sci., 91: 899-906.

\section{How to cite this article:}

Santosh Kumar, S.K. Dwivedi, Rahul Kumar, N. Bhakta, Ved Prakash, K.K. Rao, Rakesh Kumar, Shikha Yadav, Anup Kumar Choubey and J.S. Mishra. 2017. Screening of different rice germplasm against multiple disease under submergence condition in middle Indo Gangetic Plain. Int.J.Curr.Microbiol.App.Sci. 6(5): 335-339. doi: http://dx.doi.org/10.20546/ijcmas.2017.605.038 